\title{
The Relationship of Mother Knowledge Level and Exclusive Breastfeeding for Infants Aged 7-12 Months in The Public Health Center of Rappang, Sidrap District in 2017
}

\author{
Syamsuriyati ${ }^{1}$, Tahir Abdullah ${ }^{2}$, Burhanuddin Bahar $^{3}$, Andi Indahwaty ${ }^{4}$, Veni Haju ${ }^{5}$, \\ Ridwan Amiruddin ${ }^{6}$, Toto Sudargo ${ }^{7}$, syamsuar $^{8}$, Sumarni $^{9}$ \\ \{syamsuriyatiahmad@gmail.com ${ }^{1}$, mtahirabd@gmail.com ${ }^{2}$, \\ indhsidin@gmail.com ${ }^{4}$, ridwan.amir@unhas.ac.id ${ }^{6}$, syamsuar.m@unhas.ac.id ${ }^{8}$ \} \\ Public Health Faculty of Hasanuddin University Makassar ${ }^{1,3-5}$ \\ Lecture of Midwifery of STIKES Mega Rezky Makassar ${ }^{2}$
}

\begin{abstract}
The proper and right exclusive breastfeeding for infants is very important in providing biological and psychological influences for both infants and mothers. The knowledge about breastfeeding also determines the exclusive of breastfeeding for infants aged 7-12 months. The research objective was to determine and understand the relationship of the mother knowledge level and the exclusive breastfeeding for infants aged 7-12 months. The design of the research was descriptive-analytical with Cross Sectional Approach. The population was mothers who have babies, and the sample was mothers who have infants aged 7-12 months. The total respondents were 30 peoples selected from purposive sampling technique. It was analysed by chi-square with a significance level of $\rho<0.05$. The results of this research indicated that respondents as housewives $50 \%$, elementary education level $43 \%$, good knowledge level $60.0 \%$, and exclusive breastfeeding $63.3 \%$ ). There was a significant relationship between mother knowledge level and exclusive breastfeeding $(\rho$-value $=0,000)$. The higher the mother knowledge level the more they know and understand the importance of exclusive breastfeeding. The suggestion for mothers is to seek information intensively on the importance of breastfeeding for infants 0-6 months.
\end{abstract}

Keywords: Breastfeeding mothers, exclusive breastfeeding, and infants

\section{Introduction}

According to the World Health Organization, the exclusive breastfeeding is maternal breast milk given in the first six months of a newborn without other complementary foods. It does not only contain macronutrients, vitamins, and minerals but also growth factors, hormones, and protective factors. There are at least 100 components in breast milk, including substances that have not been identified and unclear its role [1].

Breast milk provides lactose, cysteine, cholesterol, and thromboplastic, which are required for the synthesis of central nervous system tissues. However, because breast milk is a perfect nutrient, it's component analysis allows us to produce substitutes to be added to formula milk. Therefore, formula milk will not perfectly like breast milk [1]. 
Although, according to Melvyn that the breast milk may be considered as perfect nutrition, its composition varies. The composition of breast milk varies from person to person, from one lactation period to another and every hour in a day. The composition of breast milk includes protein, fat, carbohydrates, mineral salts, water, and vitamins such as colostrum [1].

According to the World Health Organization, breast milk is a fat emulsion in a solution of protein, lactose and inorganic salts secreted by the maternal gland, which is useful as food for the infant [2]. Exclusive breastfeeding is breastfeeding without supplementary food and drinks for infants aged 0-6 months. Even water is not given in a stage of exclusive breastfeeding [1]. WHO explains that exclusive breastfeeding for the first six months of newborns is the best. Thus, for previous stipulation (that exclusive breastfeeding is enough for four months) is no longer valid [2].

Colostrum contains immunity substance, high vitamin A, thicker, and yellowish. Therefore, it must be given to infants. Even though the production of breast milk is less in the first few days, it was sufficient for the infant's needs. Giving sugar water, starch water, and prolactin food (before the breast milk is produced smoothly) should be avoided [1].

According to Dewi (2010) asserts that neonates are babies aged 0-28 days. Neonates are one-hour-old babies born at 37-42 weeks of gestation and 2.500-4.000 grams of weight [3]. Normal neonates have 2500-4000 grams birth weight, gestational age 37-40 weeks, cry immediately, move actively, reddish skin, suck breast milk properly, and no congenital disabilities [4].

According to Dewi (2010) that normal neonates have a body length of $48-52 \mathrm{~cm}$, chest circumference of $30-38 \mathrm{~cm}$, arm circumference of $11-12 \mathrm{~cm}$, heart rate of $120-160 \mathrm{x} / \mathrm{minute}$, breathing 40-60 x/minute, invisible lanugo and the hair of the head grows perfectly, the nails are rather long and limp, the APGAR value > 7, the reflexes are well-formed (rooting, sucking, morro, grasping), genital organs in the male baby the testicles are in the scrotum and penis perforated, in the female baby the vagina and urethra perforated and the presence of labia minora and mayoral, meconium release in the first 24 hours and brownish black [3].

Knowledge is a result of human sensing, or a result of knowing someone about an object through its senses (eyes, nose, ears, etc.) [5]. According to the Big Indonesian Dictionary (2003) that knowledge is everything that is known about things. Knowledge of cognitive is a domain that is very important for the creation of person' actions (over behavior). The level of knowledge can influence behavior; maternal knowledge is very influential for exclusive breastfeeding, this is indicated to accur increase in exclusive breastfeeding if accompanied by an increase knowledge of exclusive breastfeeding [6].

\section{Method of Research}

The design of research used is quantitative by using cross-sectional approach in which the researcher observes or measures variables at one time, each subject is only observed once and variable measurements can be done at the time of examination. 


\section{Result}

\subsection{General Description of Research Sites}

In this section, we will describe the results and discussion of research including a general description of the research site, demographic characteristics by ages, occupation and education levels, and the relationship of mother knowledge level and exclusive breastfeeding for infants aged 7 - 12 months, as follows.

\section{Background}

Public Health Center of Rappang is a health development implementing unit in Panca Rijang sub-district which was established in 1988 and is located $10 \mathrm{~km}$ in north of the capital of Sidenreng Rappang district, Pangkajene, with an area of $\pm 48 \mathrm{~km}^{2}$ with a vision "Realizes a Public Health Center of Rappang as a Quality Public Health Center and able to Provide Excellent Health Services."

The number of villages in Panca Rijang sub-district is 8 , consist of 4 villages and 4 subvillages until 2016 recorded a total population as many as 28.383 peoples. With the number of heads of households was 7.337 people.

The population in this research was total mothers who had infants aged 7-12 months who visit to the Public Health Center of Rappang when the study was conducted since April - May as many as 98 peoples while as respondents in this research is set by the inclusion criteria as many as 30 peoples and it is taken by purposive sampling method.

\section{Characteristics of respondents}

a. Distribution of respondents by age

To determine the distribution of respondents by age as the research variables can be seen in the following table:

Table 1. Distribution of respondent by Age at Public Health Center of Rappang, Sidenreng Rappang

\begin{tabular}{ccc} 
& District, 2017 & \\
\hline Ages & Number (n) & Percentage (\%) \\
(Year) & 20 & 66,7 \\
$20-30$ & 8 & 26,7 \\
$31-40$ & 2 & 6,7 \\
$>40$ & 30 & 100,0 \\
& & \\
\hline
\end{tabular}

Source: Primary data, 2017

Based on table 1 shows from 30 respondents as samples, respondents with the category of age 20 -30 years were 20 people $(66.7 \%)$. Respondents with the category of age $31-40$ years 
were 8 people $(26.7 \%)$. And the least are respondents with the category of age $>40$ years were 2 people $(6.7 \%)$.

b. Distribution of respondents by occupation

To determine the distribution of respondents by occupation can be seen in the following table.

Table 2.Distribution of the respondent by occupation at Public Health Center of Rappang, Sidenreng Rappang District, 2017

\begin{tabular}{ccc}
\hline Types of Occupation & Number (n) & Percentage (\%) \\
\hline Housewife & 15 & 50,0 \\
Public servant & 9 & 30,0 \\
Entrepreneur & 6 & 20,0 \\
Total & 30 & 100,0 \\
\hline
\end{tabular}

Source: Primary data, 2017

Based on table 2 shows from 30 respondents as samples, respondents with categories that do not work outside the home (housewife) as many as 15 people (50\%), respondents with categories that work as civil servants as many as 9 people (30\%), and respondents who work as entrepreneurs were 6 people $(20 \%)$.

c. Distribution of respondent by education level

To determine the distribution of respondents by education level can be seen in the following table:

Table 3. Distribution of respondents by education level at Public Health Center of Rappang, Sidenreng Rappang District, 2017

\begin{tabular}{ccc}
\hline Educational Level & Number (n) & Percentage (\%) \\
\hline Elementary School & 13 & 43,3 \\
Junior High School & 4 & 13,3 \\
Senior High School & 8 & 26,7 \\
College & 5 & 16,7 \\
Total & 30 & 100,0 \\
\hline
\end{tabular}

Source: Primary data, 2017

Based on table 3 shows that from 30 respondents as sample, respondents with the category of elementary education level were 13 people $(43.3 \%)$, respondents with the category of junior high school were 4 people $(13.3 \%)$, respondents with the category of high school were 8 people $(26.7 \%)$, and respondents with the category of college were 5 people $(16.7 \%)$. 


\section{Univariate Analysis}

a. Knowledge of mother

To determine the distribution of respondents by mother knowledge level can be seen in the following table:

Table 4. Distribution of respondent by mother knowledge level at Public Health Center of Rappang, Sidenreng Rappang District

\begin{tabular}{ccc}
\hline Mother Knowledge Level & Number (n) & Percentage (\%) \\
\hline Good & 18 & 60,0 \\
Less & 12 & 40,0 \\
Total & 30 & 100,0 \\
\hline
\end{tabular}

Source: Primary data, 2017

Based on table 4.4 shows from 30 respondents as samples, respondents with the category of good mother knowledge level were 18 people $(60 \%)$, and the category of poor mother knowledge level was less than 12 people $(40 \%)$.

b. Distribution of exclusive breastfeeding of respondents for infants aged 7-12 months

Table 5. Distribution of exclusive breastfeeding of respondents for infants aged 7-12 Months at Public Health Center of Rappang, Sidenreng Rappang District

\begin{tabular}{ccc}
\hline Exclusive Breastfeeding & Number (n) & Percentage (\%) \\
\hline Good & 19 & 63,3 \\
Less & 11 & 36,7 \\
Total & 30 & 100,0 \\
\hline
\end{tabular}

Source: Primary data, 2017

Based on table 4.5 shows from 30 respondents as samples, respondents with the category of good exclusive breastfeeding for infants aged 7-12 months were 19 (63.3), and respondents with the category of less exclusive breastfeeding were less than 11 people $(36.7 \%)$.

\subsection{Discussion}

In this section will be discussed about the mother knowledge level about breastfeeding, exclusive breastfeeding for infants aged 7-12 months, and the relationship of mother knowledge level and exclusive breastfeeding for infants aged 7-12 months as the specific objectives of this research the relationship of mother knowledge level and exclusive breastfeeding for infants aged 7-12 months. 
The proper and good exclusive breastfeeding is very important and also determines the growth and development of the infant.

The result of the Chi-Square test obtained $\rho$-value $(0,000)<\alpha(0,05)$. Therefore $\mathrm{H}_{0}$ is rejected, and $\mathrm{H}_{\mathrm{a}}$ is accepted. It means that there is a relationship of mother knowledge level and exclusive breastfeeding for infants aged $7-12$ months.

The education level of respondents is mostly $(43.3 \%)$ is elementary education so that the level of understanding is relatively less. Less understanding of exclusive breastfeeding will cause individuals to be unable to change behavior about exclusive breastfeeding in daily life. If someone has applied proper exclusive breastfeeding that has been understood, then habits will arise in their daily lives to implement proper and good breastfeeding.

A theory proposed by Notoatmodjoa that understanding is a second level cognitive domain. After the process of understanding, the individual will apply what he understands and then analyze, synthesize, and evaluate what has been applied.

Roger's theory cited from Notoatmodjo argues that the acceptance of new behavior or adoption of behavior based on knowledge, awareness, and positive attitudes will last a long time. Conversely, if the behavior is not based on knowledge and awareness, it will not last long.

Another factor that influences exclusive breastfeeding in this research is occupational of respondents. In this research, most respondents did not work (housewives), so more time to take care of their infants included in the proper and good exclusive breastfeeding for the infant in terms of frequency of breastfeeding, correct breastfeeding procedure, and length of breastfeeding. For mothers who work outside the home, they have relatively less time to care for their infants. The frequency of breastfeeding become les; the factor of fatigue after work also affects the physical and psychological conditions of the mother in proper and good exclusive breastfeeding.

The physical and mental health of the mother determines the good exclusive breastfeeding for their infants. The healthy physical condition of the mother can affect the quality and quantity of breast milk production. This physical factor is also related to breast anatomy, hormones, and physiology of breastfeeding. Bad breast anatomy is a handicap in breastfeeding. While physiological factors also affect exclusive breastfeeding in the process of bonding and attachment. The types of hormones associated with breastfeeding are prolactin and oxytocin. The prolactin hormone plays a role in the production of breast milk, while the oxytocin hormone plays an important role in the release of breast milk when the baby is breastfeeding. Maternal physical or emotional conditions that are not good cause the unwillingness of mothers to breastfeed their infants.

The factors of eating and medicine, which are consumed by mothers, also determine to breastfeed. Eating with quality nutrients will produce quality breast milk because breast milk is made from food substances taken from the mother' blood. Medications consumed by mothers also affect the quality and quantity of breast milk. 


\section{Conclusions}

Based on the results of the research, it can be concluded as follows:

1. In this research, most respondents have a good level of knowledge (60\%). The number of information media that presents the importance of exclusive breastfeeding and the social environment that allows respondents to get better information is a factor that influences the level of knowledge of respondents other than education.

2. Most respondents (63.3\%) give proper and good exclusive breastfeeding for their infants.

3. There is a relationship between the mother knowledge level and exclusive breastfeeding for infants aged $7-12$ months

Recommendation

1. For Health Personnel

It is expected that the health personnel always provide counseling to mothers relates to the importance of exclusive breastfeeding because more information received, the higher of knowledge.

2. For the Community

It is recommended that mothers who have infants aged $7-12$ months are expected to seek information about the importance of exclusive breastfeeding, both formally and informally.

3. For Further Researchers

It is expected that further researcher can examine other variables using other research methods.

\section{References}

[1] WHO/UNICEF. Infodatin DEPKES. 20 Januari 2017. Sidenreng Rappang. (2005)

[2] Siregar, Arifin. Pemberian ASI Ekslusif dan Faktor-faktor yang Mempengaruhinya. Universitas Sumatera Utara. pp. 1-15. (2011)

[3] Aulia Ferisa.: Asuhan Kebidanan Bayi Baru Lahir pada Bayi Ny. T Umur 1 Hari dengan Berat Badan Lahir Rendah di RSUD karangnyar.Karya Tulis Ilmuah Universitas Sebelas Maret. pp. 6-92. (2015)

[4] Rosita Syarifah. Panduan Lengkap Ibu Meneyusui. Yogyakarta : Ayanna Mangunnegaran. pp. 8-15 (2008)

[5] Notoatmodjo S. Kesehatan Masyarakat Ilmu dan Seni. Jakarta : PT Rineka Cipta. pp. 34-50. (2007)

[6] Wulandari A, Karnasih W. Hubungan Tingkat pengetahuan dan Perilaku Pemberian ASI Eksklusif pada ibu yang mempunyai bayi kurang 6 bulan di Desa Bangun Jiwo Kasihan Bantul. Pp 6-9 (2011) 